\title{
Antioxidant Activity of Endophytic Bacteria Derived from Hoya multiflora Blume Plant and Their Cellular Activities on Schizosaccharomyces pombe
}

\author{
Nabila Tsoerayya Gustia Pudjas ${ }^{1}$ Nisa Rachmania Mubarik ${ }^{1,2^{*}}$, Rika Indri Astuti $^{1,2}$, Lisdar I Sudirman ${ }^{1,2}$ \\ 'Study Program of Microbiology, Graduate School of IPB University, Bogor, Indonesia \\ ${ }^{2}$ Department of Biology, Faculty of Mathematics and Natural Sciences, IPB University, Bogor, Indonesia
}

\section{ARTICLE INFO}

Article history:

Received December 13, 2021

Received in revised form January 9, 2022

Accepted January 14, 2022

\section{KEYWORDS:}

antioxidant,

endophytic bacteria,

oxidative stress,

peroxide

\begin{abstract}
Endophytic bacteria isolated from plant tissues can produce the same secondary metabolites as their host plants. One of the metabolites that bacteria can produce is antioxidants. This research aimed to analyze and measure the antioxidant activities of two endophytic bacteria, i.e. Bacillus siamensis HMB1 and Bacillus aryabhattai HMD4 cultures, derived from Hoya multiflora Blume plant, a tropical epiphytic plant species that grows in Indonesia, and to identify their cellular effects on Schizosaccharomyces pombe. The active compounds went through extraction process, and the antioxidant activities were measured, the extracts went under phytochemical analysis, and their phenol and flavonoid contents were measured. In vitro analysis was carried out using $S$. pombe. The results of this research indicated that both bacterial crude extract had antioxidant activities, where $B$. siamensis $\mathrm{HMB1}$ showed the highest $\mathrm{IC}_{50}$ value $(51.18 \mathrm{mg} / \mathrm{ml})$ among all. In vitro analysis indicated that $B$. aryabhattai HMD4 bacterial crude extract in $250 \mathrm{ppm}$ concentration showed the highest resistance effect and significantly enhanced $S$. pombe growth. In addition, the results of the LC-MS analysis suggested that a pyridoxamine compound was detected.
\end{abstract}

\section{Introduction}

Free radicals are produced naturally by cells through respiration and metabolisms; they are among others superoxide, hydrogen peroxide, hydroxyl radicals, and singlet oxygen (Ahmadinejad et al. 2017). The cell keeps reactive oxygen species (ROS) in low concentrations (Rahal et al. 2014). ROS in high concentration can cause oxidative modification of the main macromolecules of cells, such as protein, lipid, and DNA, and the oxidation can eventually induce apoptosis (Avery 2011). Imbalanced concentration between free radicals and antioxidants can lead to oxidative stress conditions, and ROS will be extremely hazardous (Izyumov et al. 2010). Oxidative stress has been used in many conditions, such as atherosclerosis, inflammatory condition, certain cancer, and the process of aging (Lobo et al. 2010). To prevent the effect of free radicals, compounds that can inhibit the oxidation process by ROS are crucial, i.e. antioxidants.

\footnotetext{
* Corresponding Author

E-mail Address: nrahcmania@apps.ipb.ac.id
}

Antioxidants can degrade free radicals (Turan 2010). According to Mishra et al. (2015), the number of antioxidants available in the body cannot compare with the number of free radicals that enter the body. Therefore, to prevent cell damage caused by free radicals, an additional intake of antioxidants is necessary. Although commonly derived from plant metabolites, antioxidants can also be produced by bacteria, such as endophytic bacteria from Hoya multiflora plant. Endophytic microbes are the microbes that can colonize the internal part of plant tissues in a certain period of its life cycle (Mano and Morisaki 2008). The bacteria that have been isolated from a plant have the ability to produce the same secondary metabolites as their host plant and even in a greater amount (Radji 2005).

Antioxidant activity can be analyzed using spectrophotometry, electrochemical assay, and chromatography (Pisoschi and Negulescu 2011). The activity can be determined using a radical compound named DPPH (1.1-diphenyl-2-picrylhydrazyl), and it is indicated by its color change. Initially colored purple, DPPH turns yellowish upon reacting with antioxidants and can be observed at $517 \mathrm{~nm}$ 
wavelength (Molyneux 2004). The antioxidant effect can also be identified using model organisms such as S. pombe. The yeast shares several similarities with human cells, such as in its mRNA splicing process, DNA repair, cell fission, and telomere function (Chen and Runge 2009).

Hoya multiflora Blume is a tropical epiphyte plant that belongs to the family Apocynaceae and the subfamily Asclepiadoideae (Endress and Bruyns 2000). Hoya can be found in Indonesia and is used as a medicinal as well as an ornamental plant (Rahayu et al. 2011). The increasing international trade and the exploitation in its natural habitats have threatened the presence of the species in nature. Therefore, studying and exploring Hoya should be carried out in an alternative way, such as by utilizing its endophytic bacteria. A previous study by Alvionita et al. (2020) indicated that two strains of endophytic bacteria from Hoya, i.e. Bacillus siamensis HMB1 and Bacillus aryabhattai HMD4 cultures have antibacterial activities. Metabolite extracts from these cultures contained several compounds potentially having antioxidant activities, although they had not been measured yet. In the present study, antioxidant activity was measured, phytochemical analysis was performed, and the amounts of phenols and flavonoids were measured. In addition, the cellular effects of both cultures on Schizosaccharomyces pombe under oxidative stress were also analyzed.

\section{Materials and Methods}

\subsection{The Production and the Extraction of Active Compounds using Phytochemical Analysis}

The production of active compounds was carried out following Prastya et al. (2018) by inoculating one loop of each B. siamensis HMB1 and B. aryabhattai HMD4 cultures on nutrient broth (NB) media. $1 \%$ bacterial culture liquid was then inoculated onto production media and put in an incubator for three days on a $120 \mathrm{rpm}$ orbital shaker at room temperature. The supernatant was obtained through centrifugation before being mixed with ethyl acetate in a 1:1 ratio and shaken for 20 minutes. To collect crude bacterial extract, the ethyl acetate layer was separated using a separator funnel and then evaporated.

\subsection{The Measurement of Phenols and Flavonoids}

Phenolic compounds were measured following Lim and Murtijaya (2007). Gallic acid was used as the standard. $1 \mathrm{ml}$ bacterial crude extract diluted solution was prepared and added with $5 \mathrm{ml}$ Folin-Ciocalteau before homogenization and incubation for 8 minutes. The absorbance was measured at $730 \mathrm{~nm}$ and its linear regression was measured. The total phenolic content of the bacterial crude extract was determined based on the equivalent of total mg gallic acid per extract $\operatorname{gram}(\mathrm{EGA} / \mathrm{g})$.

Flavonoid compounds were measured using quercetin as the standard following Vongsak et al. (2013). The extract solution was mixed with $2 \%$ chloric acid in a $1: 1$ ratio prior to being homogenized and incubated for 30 minutes. The absorbance was measured at $415 \mathrm{~nm}$, and its linear regression was also measured. The total flavonoid compounds of the bacterial crude extract was determined based on the equivalent of total mg quercetin per extract gram $(\mathrm{EQ} / \mathrm{g})$.

\subsection{The Measurement of Antioxidant Activity using DPPH Assay}

The antioxidant activity was measured following Batubara et al. (2009) using DPPH (1.1-diphenyl-2picrylhydrazyl) as the radicals. DPPH solution (125 $\mu \mathrm{M}$ ) was mixed with the bacterial crude extract that had been diluted into several concentrations. The solution was incubated at darkroom temperature for 30 minutes, and the absorbance was then measured at $\mathrm{OD}_{515}$. Ascorbic acid was also measured as the standard. The inhibitory concentration at $50 \%$ radicalsscavenging activity $\left(\mathrm{IC}_{50}\right)$ was then determined.

\subsection{Resistance Analysis using In Vitro Assay}

Resistance analysis using in vitro assay was carried out using S. pombe as the model organism. A qualitative assay, i.e. spot assay, was also carried out following Prastya et al. (2018) with several modifications. The inoculum of $S$. pombe was re-inoculated into $3 \mathrm{ml} \mathrm{YES}$ (yeast extract with supplement) with an initial $\mathrm{OD}_{600}$ of 0.05 . The bacterial crude extract was diluted in DMSO and used as a supplement for the treatment cultures. Ascorbic acid (5 ppm) was used as the positive control and DMSO as the negative control. Each culture was 
incubated in a shaker at $300 \mathrm{rpm}$ for a day before being inoculated by spotting on YES containing several concentrations of peroxide $\left(\mathrm{H}_{2} \mathrm{O}_{2}\right)$. Spotting yeast is started with initial absorbance of $0.1 \mathrm{OD}_{600}$, and followed by serai dilution(10-1-10-4) from left to right with $2 \mu$ f for each spot. In addition, a quantitative assay was performed using the Total Plate Count (TPC) method following Batubara et al. (2020) with several adjustments. The yeast was grown in the same step series as the qualitative method, and the cultures were then mixed with $5 \mathrm{mM} \mathrm{H}_{2} \mathrm{O}_{2}$ before being incubated for another $24 \mathrm{~h}$. The number of the colonies was counted using the TPC method after growing them in YES solid media.

The resistance analysis then continued by measurement of intracellular catalase activity. The analysis started with preparing yeast cells, and it was performed according to Martins and English (2014). Then the supernatant was analyzed its catalase activity by following Senthilkumar et al. (2021) and also its protein concentration according to Bradford (1976) by using bovine serum albumin as standard. The activity was presented in activity percentage.

\subsection{Liquid Chromatography-Mass Spectrometry Analysis}

The bacterial crude extract (10 $\mathrm{mg}$ ) was prepared and diluted in $5 \mathrm{ml}$ ethanol before being filtrated using PTFE $0.2 \mu \mathrm{m}$, while LC-MS analysis was performed using UHPLC Vanquish Tandem Q Exactive Plus Orbitrap HRMS (ThermoScientific Waltham, Ma, USA). In addition, Accucore C18, $100 \times 2.1 \mathrm{~mm}, 1.5 \mu \mathrm{m}$ was used for LC Separation. The flow rate of $0.2 \mathrm{ml} / \mathrm{min}$ was used, and $\mathrm{H}_{2} \mathrm{O}+0.1 \%$ formic acid (A) and acetonitrile + $0.1 \%$ formic acid was used as the eluents. The gradient was set at 0-1 min (5\%B), 1-2 min (5-95\%), 25-28 $\min (95 \% \mathrm{~B})$, and $28-30 \mathrm{~min}(5 \% \mathrm{~B})$. The temperature was set at $30^{\circ} \mathrm{C}$ and $5 \mu$ of bacterial crude extract was then injected. HESI (Electrospray ionization) was also employed and was operated in positive ionization mode. The mass spectrometer was operated in 100$1,500 \mathrm{~m} / \mathrm{z}$. ChemSpider was used to analyze the results, i.e. by matching the fragmentation spectra and the compounds.

\section{Results}

After $72 \mathrm{~h}$ of incubation, a total of $0.2 \mathrm{~g}$ and $0.1 \mathrm{~g}$ bacterial crude extracts were obtained respectively from $1,500 \mathrm{ml}$ culture of $B$. siamensis HMB1 and $B$. aryabhattai HMD4. The extracts appeared black and yellowish-green in powdered form.

For both cultures, the $\mathrm{IC}_{50}$ the crude extract of both cultures was higher than that of the ascorbic acid used as the positive control (Table 1). Among these two sample sources, the highest $\mathrm{IC}_{50}$ was shown by $B$. siamensis HMB1 bacterial crude extract. $B$. siamensis HMB1 was found to have a higher amount of phenolic compounds than B. aryabhattai HMD4. Although the flavonoids in both samples were found lower than the phenols, B. aryabhattai HMD4 had higher flavonoids than $B$. siamensis HMB1.

The in vitro antioxidant activity assay was carried out using S. pombe, where the viability of the yeast was used as the parameter showed that yeast growth without any treatment decreased along with the increase in peroxide concentration (Figure 1). At zero concentration of peroxide, the yeast managed to grow up to the third dilution (10-3), while at the highest concentration of peroxide $(2 \mathrm{mM})$, yeast could only survive up to the first dilution (10-1). The decreasing growths of $S$. pombe, where without bacterial crude extract and ascorbic acid the species had the lowest number of colonies (Figure 2).

S. pombe supplemented with B. siamensis HMB1 and $B$. aryabhattai HMD4 bacterial crude extracts as well as ascorbic acid increased viability of $S$. pombe. At the highest concentration of peroxide $(2 \mathrm{mM})$ and $250 \mathrm{ppm}$ bacterial crude extract of $B$. siamensis HMB1, the yeast managed to survive up to the second dilution (10-2), while B. aryabhattai HMD4 bacterial crude extract increased the yeast's resistance level up to the third dilution (10-3). This cellular effect on increasing viability and resistance of $S$. pombe was as good as the effect of $5 \mathrm{ppm}$ ascorbic acid that was used as the positive control. Surprisingly, even though based on the DPPH assay results the activity of $B$. aryabhattai HMD4 was lower than that of $B$. siamensis HMB1, B. aryabhattai HMD4 showed greater effects on increasing the viability of $S$. pombe in spot assay. This was indicated by the survival of the yeast up to the third dilution (10-3). As the best results were found in B. aryabhattai HMD4, the analysis was then continued to focus on the effect of B. aryabhattai HMD4 by measuring the number of the yeast colonies. The numbers of the colonies of yeast supplemented with $B$. aryabhattai HMD4 bacterial crude extract plates were found to be significantly different, where the yeast with $B$. aryabhattai HMD4 bacterial crude extract supplement grew in the highest total of colonies, followed by yeast supplemented with ascorbic acid (Figure 2).

The cellular activity of bacterial crude extract on $S$. pombe was also observed by its intracellular catalase (Figure 3 ). The culture that was given peroxide induction significantly would produce higher catalase activity than the culture without any induction. The catalase activity of induced culture 
Table 1. The results of DPPH assay measurement, phenol and flavonoid content

\begin{tabular}{lccc}
\hline Sources & $\mathrm{IC}_{50}(\mathrm{mg} / \mathrm{ml})$ & $\mathrm{mg}$ phenol $(\mathrm{EAG} / \mathrm{g})$ & $\mathrm{mg}$ flavonoid $(\mathrm{EQ} / \mathrm{g})$ \\
\hline HMB1 & $51.18 \pm 0.19$ & $26.17 \pm 0.48$ & $8.70 \pm 0.17$ \\
HMD4 & $54.15 \pm 0.19$ & $16.86 \pm 0.59$ & $9.83 \pm 0.24$ \\
Ascorbic acid & $4.22 \pm 0.09$ & - & - \\
\hline
\end{tabular}

Values were the means and standard deviation of three replication experiments. Sources of HMB1 and HMD4 that were used are the bacterial crude extract. $\mathrm{IC}_{50}$ indicates the ability of bacterial crude extract and ascorbic acid on degrading $50 \%$ of DPPH $125 \mu \mathrm{M}$ solution

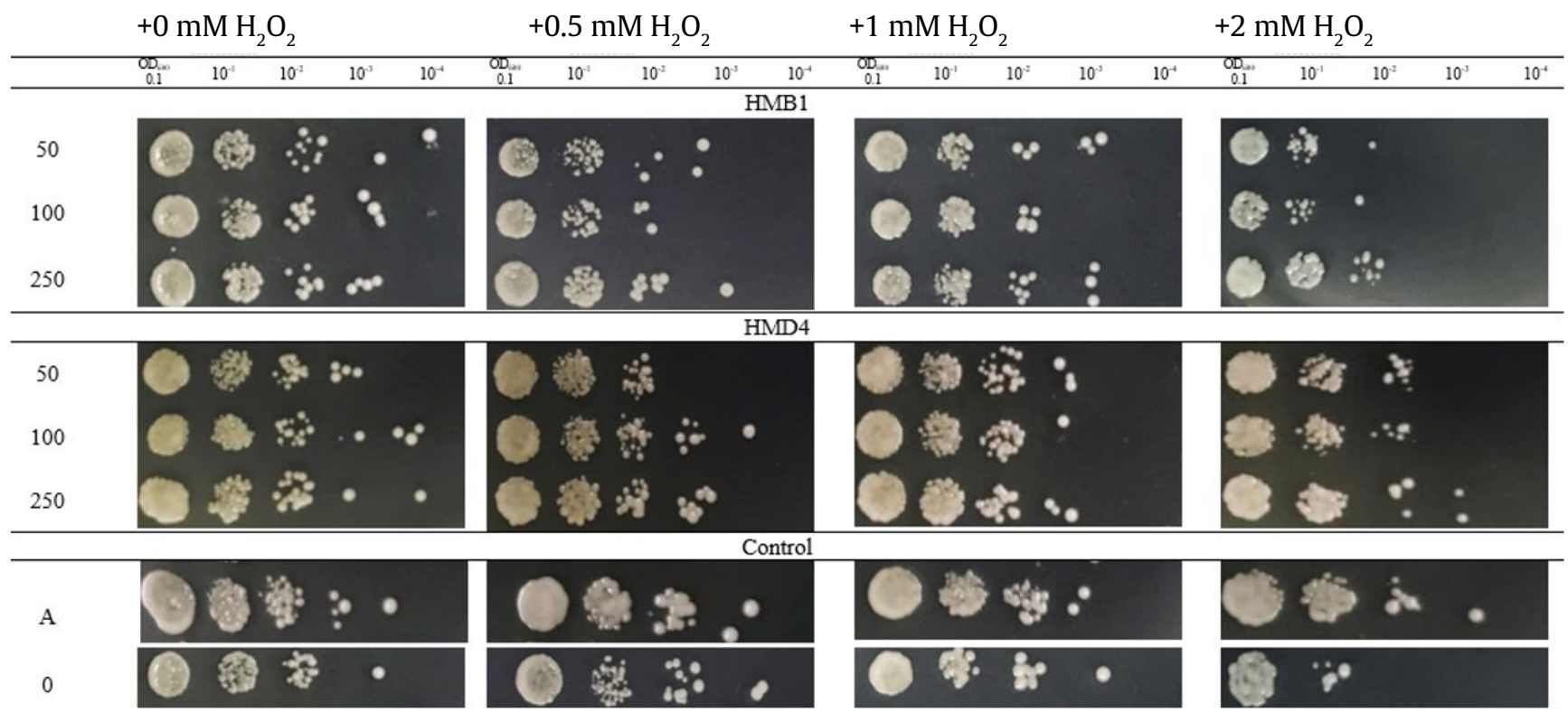

Figure 1. Spot assay result on observing viability of yeast $S$. pombe in several concentrations of peroxide $(0,0.5,1$, and 2 $\mathrm{ppm})$ after $72 \mathrm{~h}$ incubation. The controls were A: Ascorbic acid (5 ppm) and 0: DMSO only, while the treatment of two bacterial crude extracts consist of 50,100, and $250 \mathrm{ppm}$ concentrations. S. pombe was spotted in the same initial $0.1 \mathrm{OD}_{600}$ absorbances (started on the left side), followed by serial 10-1 to 10-4 dilution, the density of yeast decreased on the next dilution

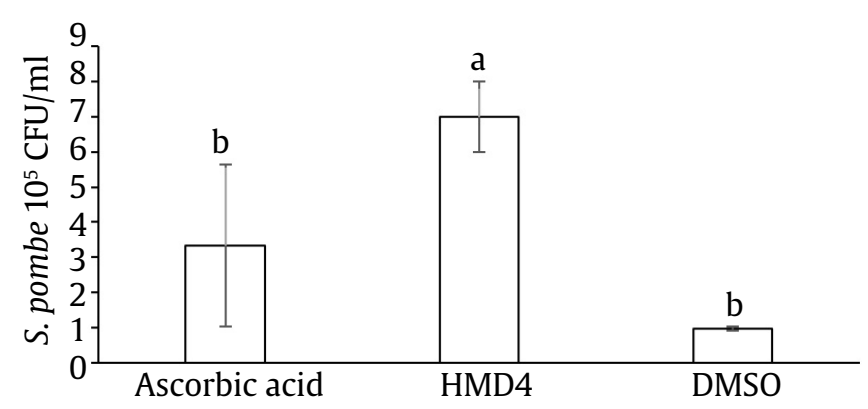

Figure 2. The total colony of $S$. pombe under oxidative stress. The values are means and standard deviation on the graph was counted from three replication experiments. Bacterial crude extract of B. aryabhattai HMD4 (250 ppm) treatment was significantly different which was determined by ANOVA followed by Tukey test range (a-bp $<0.05$ ) and which supplemented with $B$. aryabhattai HMD4 bacterial crude extract has a lower activity than ascorbic acid, but this effect is not significant based on statistical analysis.

The results of the LC-MS analysis of B. aryabhattai HMD4, which was the best bacterial crude extract, indicated, there was a pyridoxamine compound that based on literature has antioxidant properties. The characteristic of the pyridoxamine compound obtained from LC-MS analysis showed that the compound's molecular weight was 168.09 , and the formula was $\mathrm{C}_{8} \mathrm{H}_{12} \mathrm{~N}_{2} \mathrm{O}_{2}$ with 2.17 on retention time (Figure 4). 


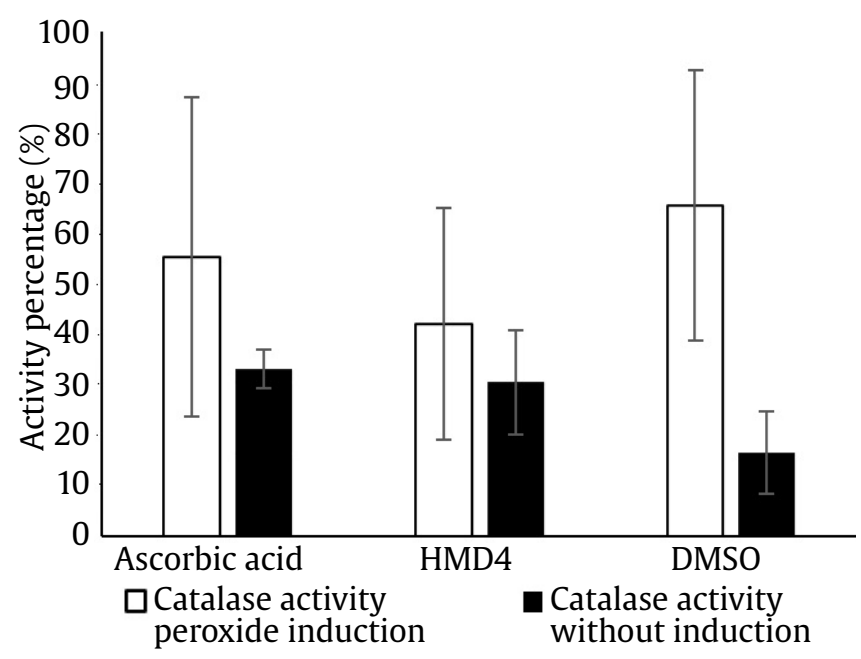

Figure 3. The intracellular catalase activity of $S$. pombe under oxidative stress. The values are the means and standard deviation of four replication experiments. S. pombe with induction and without induction had significantly different catalase activity, but between bacterial crude extract of B. aryabhattai HMD4 (250 ppm), positive control ascorbic acid (5 ppm), and negative control DMSO there is no significant differences which determined by ANOVA followed by Tukey test range $(p<0.05)$. But the catalase activity of HMD treatment of induced $S$. pombe culture were the lowest

\section{Discussion}

One of the most important steps of this research was the extraction process. The ethyl acetate used in the process was the semi-polar dilution one, making it to be able to bind both polar and nonpolar compounds. From the antioxidant activity assay, both of endophytic bacterial extracts were found to have antioxidant activities, indicating that both produced antioxidant compounds. Several endophytic bacteria were found to be able to produce antioxidants in prior studies, for example, Paenibacillus alvei derived from Curcuma longa plant (Sulistiyani et al. 2016), Staphylococcus sp. strain ACP3 derived from Morinda citrifolia (Rabima et al. 2020), and B. tequilensis, B. subtilis, and Strenotrophomonas maltophilia derived from Fagonia indica (Rahman et al. 2017).

The higher amount of phenolic content in $B$. siamensis HMB1 bacteria crude extract was correlated to its higher antioxidant activity compared to $B$. aryabhattai HMD4. Paixão et al. (2007) stated that there is a correlation between phenolic content and antioxidant activity. Wojdyło et al. (2007) also mentioned that in several herbal plants, there is a high correlation between antioxidant activity and the total phenolic compound, and HPLC analysis indicates that phenolic compounds are the dominant

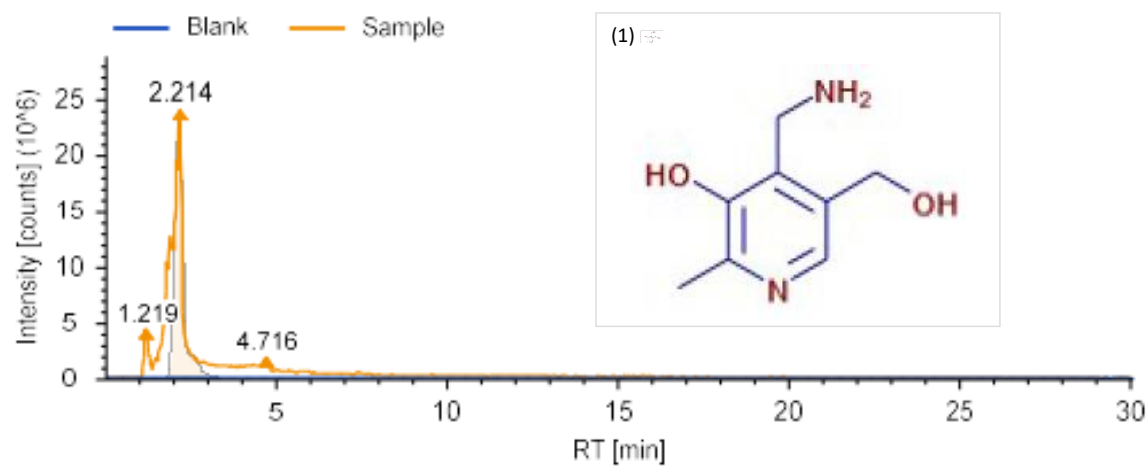

(2).

HMD4 (F2) \#558, RT=2.179 min, MS1, FTMS (+) $\mathrm{C} 8 \mathrm{H} 12 \mathrm{~N} 2 \mathrm{O} 2$ as $[\mathrm{M}+\mathrm{H}]+1$

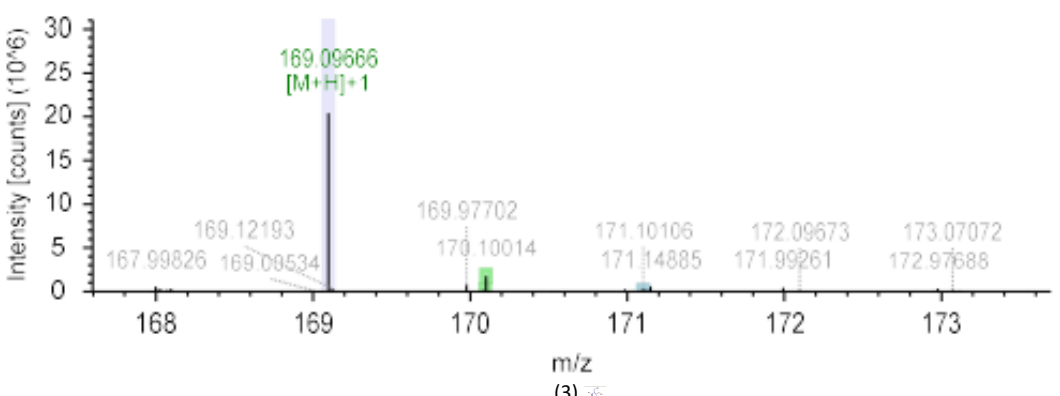

(3)

Figure 4. Pyridoxamine compound that was detected by LC-MS analysis. $(1=$ the structure of pyridoxamine where the $\mathrm{OH}$ groups on $\mathrm{C} 3$ can be released to neutralize free radicals, $2=$ the retention time of pyridoxamine, $3=$ the molecular weight of pyridoxamine) 
components in antioxidant activities. Sariwati et al. (2019) also explained that there was a correlation between total phenol and antioxidant activity, as well as the $\mathrm{IC}_{50}$ from Anthurium hookerii leaves extract. Phenolic compounds are known as primary antioxidants. The compounds have two mechanisms to neutralize free radicals, i.e. through hydrogen atom transfer (HAT) or single electron transfer (SET) (Amarowicz and Pegg 2019). Phenols and flavonoids are secondary metabolite compounds that are the main components of antioxidants (Aryal et al. 2019; Zhou et al. 2019). The compounds are able to protect organisms from hazardous oxidation (Kada et al. 2017; Wang et al. 2019).

The growth of $S$. pombe without any treatment decreased along with the increase in peroxide concentration. The inability of endogenous protection in cells to fight against free radicals causes oxidative stress. A high number of ROS (reactive oxygen species) can damage the main macromolecules of cells. Sinaga (2016) stated that oxidative stress occurred when there is a high concentration of ROI (reactive oxygen intermediate), which is toxic and cannot be neutralized by our body. This condition will lead free radicals to react with nucleic acid, protein, and lipid, causing organ dysfunctions. Proteins oxidized by ROS will eventually accumulate, forming protein aggregate, and the proteins lose their functions. Therefore, this condition will lead to apoptosis (programmed cell death) (Avery 2011). This was the reason why $S$. pombe in this study could only survive until the first dilution (10-1).

The $\mathrm{IC}_{50}$ of $B$. siamensis HMB1 bacterial crude extract was lower than $B$. aryabhattai HMD4. IC $_{50}$ is the antioxidant concentration needed to reduce $50 \%$ of the DPPH concentration (Granadoz-guzman et al. 2017). So that B. siamensis HMB1 bacterial crude extract has a better antioxidant effect. But according to Kusumawati and Indrayanto (2013), the in vitro analysis only showed reaction on the given system, in this case, it would make the correlation with in vitro analysis won't be certain. This statement was proven where in this research, where B. arabhattai HMD4 bacterial crude extract that had a low activity on DPPH assay, has a better activity on in vitro promoting viability of $S$. pombe under oxidative stress.

Roux et al. (2006) explained that increasing the resistance level of $S$. pombe can enhance the growth of yeast under oxidative stress. Cells require compounds from the outside of the cell that can help protect them from free radicals. Such protection can be from vitamin C, carotenoid, polyphenol, and flavonoids (Ahmadinejad et al. 2017). Phenols contained in bacterial crude extract and flavonoids work as antioxidants by deactivating single protein species through physical and synergetic effects (Casadey et al. 2019). Therefore, these compounds are able to increase the resistance level of S. pombe and eventually its growth. In this study, the ascorbic acid treatment was found to be able to make the yeast grow better than the yeast without treatment (DMSO). In addition, qualitatively, out of the two bacterial crude extracts, $B$. aryabhattai HMD4 showed better effects than $B$. siamensis HMB1, and it also significantly enhanced the growth of $S$. pombe under oxidative stress. The activity of antioxidants could be divided into three types, primary, secondary and tertiary. Primary antioxidants could prevent the formation of new free radicals, whereas secondary antioxidants can act as radical scavengers, and tertiary antioxidants can repair damaged macromolecules that are caused by free radicals (Birangane et al. 2011). But, the specific effect of the $B$. aryabhattai HMD4 bacterial crude extract still could not be defined and need a further analylisis.

In this research, intracellular catalase activity was measured. Cell naturally has enzymatic antioxidants or other natural substances that have antioxidant activity that could neutralize free radicals. Primary protection of the cellagainst free radicalconsistof three enzymes, they are glutathione peroxide, superoxide dismutase, and catalase (Shebis et al. 2013). S. pombe has catalase activity for the metabolism process and also peroxide detoxification (Lock et al. 2018). Based on Prasetya et al. (2018), inducing S. pombe with peroxide could enhance catalase production. B. aryabhattai HMD4 bacterial crude extract and also ascorbic acid become antioxidant to $S$. pombe culture that was under peroxide stress oxidation so that radical substances will be neutralized and there was no need for extra catalase production. And $S$. pombe without any treatment (DMSO only), the lack of enzyme production is probably caused by high oxidative stress that causes cell death so that the activity that had been measured was the lowest.

Based on the results of the LC-MS analysis, pyridoxamine compounds were found to have antioxidant activities. Pyridoxamine is the activated version of the $\mathrm{B} 6$ vitamin derivate (Caldes et al. 2011). Pyridoxamine could act as a radical scavenger for $\mathrm{CO}$ species that were produced on lipid and glucose degradation and also could neutralize radical compounds by releasing proton on $\mathrm{OH}$ group on $\mathrm{C} 3$ (Voziyan et al. 2005). Pyridoxamine can be produced by microbes, such as Sinorhizobium meliloti (Tazoe et al. 1999), Escherichia coli and B. subtilis (Sakai et al. 2004; Raschle et al. 2005). Only a little number of literature studied about pyridoxamine producing pathway in bacteria, and there was no report mentioning $B$. aryabhattai culture that produces this 
compound. So that, further study of pyridoxamine compound from $B$. aryabhattai HMD still needs to determine its promising activity.

In conclusion, based on the assessment of the endophytic bacterial crude extracts in this study, both B. siamensis HMB1 and B. aryabhattai HMD4 bacterial crude extracts showed antioxidant activities, whereas B. aryabhattai HMD4 in $250 \mathrm{ppm}$ concentration showed the best effect among all. In addition, in vitro analysis using $S$. pombe indicated that $B$. aryabhattai HMD4 showed a significant effect on increasing $S$. pombe's resistance level under oxidative stress. Finally, based on the results of the LC-MS Analysis, pyridoxamine was detected and potentially has antioxidant activities based on literature studies.

\section{Acknowledgements}

The authors thank the Ministry of Finance of the Republic of Indonesia for funding this research through the 2019 LPDP Scholarship Scheme.

\section{References}

Ahmadinejad, F., Møller, S.G., Hashemzadeh-Chaleshtori, M., Bidkhori, G., Jami, M.S., 2017. Molecular mechanisms behind free radical scavengers' function against oxidative stress. Antioxid. 6, 51. https://doi. org/10.3390/antiox6030051

Alvionita, D.N., Rahayu, S.R.I., Mubarik, N.R., 2020. Characterization, identification, and analysis of bioactive compound of endophytic bacteria from Hoya multiflora Blume. Biodiv. 2, 195-202. https:// doi.org/10.13057/biodiv/d210125

Amarowicz, R., Pegg, R.B., 2019. Natural antioxidants of plant origin. Adv. Food. Sci. Nutr. 90, 1-81. https:// doi.org/10.1016/bs.afnr.2019.02.011

Aryal, S., Baniya, M.K., Danekhu, K., Kunwar, P., Gurung, R., Koirala, N., 2019. Total phenolic content, flavonoid content and antioxidant potential of wild vegetables from western Nepal. Plants. 8, 96-108. https://doi. org/10.3390/plants8040096

Avery, S.V., 2011. Molecular targets of oxidative stress. Biochem. J. 434, 201-210. https://doi.org/10.1042/ BJ20101695

Batubara, I., Astuti, R.I., Prastya, M.E., Ilmiawati, A., Maeda, M., Suzuki, M., Hamamoto, A., Takemori, H., 2020. The antiaging effect of active fractions and ent-11 $\alpha$ hydroxy-15-oxo-kaur-16-en-19-oic acid isolated from Adenostemma lavenia (L.) o. kuntze at the cellular level. Antioxid. 9, 1-14. https://doi.org/10.3390/ foods9010073

Batubara, I., Mitsunaga, T., Ohashi, H., 2009. Screening antiacne potency of Indonesian medicinal plants: antibacterial, lipase inhibition, and antioxidant activities. J. Wood. Sci. 55, 230-235. https://doi. org/10.1007/s10086-008-1021-1

Birangane, R. S., Chole, D. G., Reddy, K., Shivaji, 2011. A review of antioxidants. J. Indian. Aca. Oral. Med. Rad. 23, 351353. https://doi.org/10.5005/jp-journals-10011-1167

Bradford, M.M., 1976. A rapid and sensitive method for the quantitation of microgram quantities of protein utilizing the principle of protein-dye binding. Anal. Biochem. 72, 248-254. https://doi.org/10.1016/00032697(76)90527-3
Caldes, C., Villanova, B., Adrover, M., Munoz, F., Donoso, J., 2011. Phenol group in pyridoxamine acts as a stabilizing element for its carbinolamines and schiff bases. Chem. Biodivers. 8, 1318-1332. https://doi. org/10.1002/cbdv.201000296

Casadey, R., Challier, C., Senz, A., Criado, S., 2019. Antioxidant ability of tyrosol and derivative-compounds in the presence of $\mathrm{O}_{2}(1 \Delta \mathrm{g})$-species. Studies of synergistic antioxidant effect with commercial antioxidants. Food. Chem. 28, 275-281. https://doi.org/10.1016/j. foodchem.2019.01.161

Chen, B.R., Runge, K.W., 2009. A new Schizosaccharomyces pombe chronological lifespan assay reveals that caloric restriction promotes efficient cell cycle exit and extends longevity. Exp. Gerontol. 44, 493-502. https://doi.org/10.1016/j.exger.2009.04.004

Endress, M.E., Bruyns, P.V., 2000. A revised classification of the Apocynaceae. Botanical. Rev. 66, 1-56. https://doi. org/10.1007/BF02857781

Granadis-Guzman, G., Salazar-Aranda, R., Garza-Tapia, M., Castro-Rios, R., Waksman, T.N., 2017. Terpenoids as plant antioxidants. Vit. Hormones. 72, 505-535.

Izyumov, D.S., Domnina, L.V., Nepryakhina, O.K., Avetisyan, A.V., Golyshev, S.A., Ivanova, O.Y., Korotetskaya, M.V., Lyamzaev, K.G., Pletjushkina, O.Y., Popova, E.N., 2010. Mitochondria as source of reactive oxygen species under oxidative stress. Study with novel mitochondria-targeted antioxidants - The "Skulachev- Ion" derivatives. Biochem. 75, 123-129. https://doi.org/10.1134/S000629791002001X

Kada, S., Bouriche, H., Senator, A., Demirtas, I., Özen, T., Toptanci, B.C., Kizil, G., Kizil, M., 2017. Protective activity of Hertia cheirifolia extracts against DNA damage, lipid peroxidation and protein oxidation. Pharmaceut. Biol. 55, 330-337. https://doi.org/10.10 80/13880209.2016.1261907

Kusumawati, I., Indrayanto, G., 2013. Natural antioxidant in Cosmetics. Stud. Nat. Prod. Chem. 40, 485-505. https:// doi.org/10.1016/B978-0-444-59603-1.00015-1

Lim, Y.Y., Murtijaya, J., 2007. Antioxidant properties of Phyllanthus amarus extracts as affected by different drying methods. Food. Sci. Tech. 40, 1664-1669. https://doi.org/10.1016/j.lwt.2006.12.013

Lobo, V., Patil, A., Phatak, A., Chandra, N., 2010. Free radicals, antioxidants and functional foods: impact on human health. Pharmacog. Rev. 4, 118-126. https://doi. org/10.4103/0973-7847.70902

Lock, A., Rutherford, K., Harris, M.A., Wood, V., 2018. PomBase: the scientific resource for fission yeast. Method. Mol. Biol. 1757, 49-68. https://doi.org/10.1007/978-14939-7737-6_4

Mano, H., Morisaki, H., 2008. Endophytic bacteria in the rice plant. Microbes. Environ. 23, 109-117. https:// doi.org/10.1264/jsme2.23.109

Martins, D., English, A.M., 2014. Catalase activity is stimulated by $\mathrm{H}_{2} \mathrm{O}_{2}$ in rich culture medium and is required for $\mathrm{H}_{2} \mathrm{O}_{2}$ resistance and adaptation in yeast. Redox. Biol. 2, 308-313. https://doi.org/10.1016/j.redox.2013.12.019

Mishra, V., Shah, C., Mokashe, N., Chavan, R., Yadav. H., Prajapati, J., 2015. Probiotics as potential antioxidants: a systematic review. J. Agric. Food. Chem. 63, 36153626. https://doi.org/10.1021/jf506326t

Molyneux, P., 2004. The use of stable free radical diphenylpicrylhydrazyl (DPPH) for estimating antioxidant activities. Songklanakarin. J. Sci. Technol. 26, 211-219.

Paixão, N., Perestrelo, R., Marques, J. C., Câmara, J. S., 2007. Relationship between antioxidant capacity and total phenolic content of red, rosé and white wines. Food. Chem. 105, 204-214. https://doi.org/10.1016/j. foodchem.2007.04.017 
Pisoschi, A.M., Negulescu, G.P., 2011. Methods for total antioxidants activity determination: a review. Biochem. Anal. Biochem. 1, 1-10.

Prastya, M.E., Astuti, R.I., Batubara, I., Wahyudi, A.T., 2018. Bacillus sp. SAB E-41-derived extract shows antiaging properties via ctt1-mediated oxidative stress tolerance response in yeast Schizosaccharomyces pombe. Asian. Pacific. J. Tropic. Biomed. 8, 533-539. https://doi.org/10.4103/2221-1691.245958

Rabima, Harlim, L., Sogandi., 2020. Bioactive compound analysis and antioxidant activity of endophytic bacterial extract from Noni fruits (Morinda citrifolia L.). In: Proceedings IOP Conference Series: Earth Environ Sci, Malang, Vol 475. Bristol: IOP Publishing Ltd. pp. 1-7. https://doi.org/10.1088/1755-1315/475/1/012077

Radji, M., 2005. Peranan bioteknologi dan mikroba endofit dalam pengembangan obat herbal. Majalah. Ilmu. Kefarmasian. 2, 113-126. https://doi.org/10.7454/ psr.v2i3.3388

Rahal, A., Kumar, A., Singh, V., Yadav, B., Tiwari, R., Chakraborty, S., Dhama, K., 2014. Oxidative stress, prooxidants, and antioxidants: the interplay. Bio. Med. Res. Int. 2014, 1-19. https://doi.org/10.1155/2014/761264

Rahayu, S., Abdulhadi, R., Risna, R.A., Kusuma, Y.W.C., 2011. Habitat diversity of Hoya Multiflora Blume in Bodogol research's station, Gunung Gede Pangrango national park. In: Proceedings of Seminar Nasional HUT Kebun Raya Cibodas Ke-159, Cibodas, Vol 1. Cibodas: UPT Balai Konservasi Tumbuhan Kebun Raya Cibodas-LIPI. pp. 367-372.

Rahman, L., Shinwari, Z.K., Iqrar, I., Rahman, L., Tanveer, F., 2017. An assessment on the role of endophytic microbes in the therapeutic potential of Fagonia indica. Ann. Clin. Microbiol. Antimicrob. 16, 53-65. https://doi.org/10.1186/s12941-017-0228-7

Raschle, T., Amrhein, N., Fitzpatrick, T.B., 2005. On the two components of pyridoxal 5'-phosphate synthase from Bacillus subtilis. J. Biol. Chem. 280, 32291-32300. https://doi.org/10.1074/jbc.M501356200

Roux. A.E., Quissac, A., Chartrand, P., Ferbeyre, G., Rokeach, L.A., 2006. Regulation of chronological aging in Schizosaccharomyces pombe by the protein kinases Pka1 and Sck2. Aging. Cell. 5, 345-357. https://doi. org/10.1111/j.1474-9726.2006.00225.X

Sakai, A., Kita, M., Tani, Y., 2004. Recent progress of vitamin B6 biosynthesis. J. Nutr. Sci. Vitaminol. 50, 69-77. https://doi.org/10.3177/jnsv.50.69

Sariwati, A., Fitri, I., Purnomo, A.S., Fatmawati, S., 2019. Phytochemical, antibacterial and atioxidant activities of Anthurium hookerii leaves extract. Hayati. J. Biosci. 26, 101-109. https://doi.org/10.4308/hjb.26.3.101
Shebis, Y., Iluz, D., Kinel-Tahan, Y., Dubinsky, Z., Yehoshua, Y., 2013. Natural antioxidants: function and sources. Food. Nutri. Sci. 4, 643-649. https://doi.org/10.4236/ fns.2013.46083

Sinaga, F.A., 2016. Stress oksidatif dan status antioksidan pada aktivitas fisik maksimal. J. Generasi. Kampus. 9, 176-189.

Senthilkumar, M., Amaresan, N.S.A., Sankaranarayanan, A., 2021. Plant-Microbe Interaction, Laboratory techniques. Springer Protocols Handbooks. New York: Humana. https://doi.org/10.1007/978-1-0716-1080-0

Sulistiyani, S., Ardyati, T., Winarsih, S., 2016. Antimicrobial and antioxidant activity of endophyte bacteria associated with Curcuma longa rhizome. J. Exp. Life. Sci. 6, 45-51. https://doi.org/10.21776/ub.jels.2016.006.01.11

Tazoe, M., Ichikawa, K., Hoshino, T., 1999. Production of vitamin B6 in Rhizobium. Biosci. Biotechnol. Biochem. 63, 1378-1382. https://doi.org/10.1271/bbb.63.1378

Turan, B., 2010. Role of antioxidants in redox regulation of diabetic cardiovascular complications. Current. Pharm. Biotechnol. 11, 819-836. https://doi. org/10.2174/138920110793262123

Vongsak, B., Sithisarn, P., Mangmool, S., Thongpraditchote, S. Wongkrajang, Y., Gritsanapan, W., 2013. Maximizing total phenolics, total flavonoids contents and antioxidant activity of Moringa oleifera leaf extract by the appropriate extraction method. Industr. Crops. Products. 44, 566-571. https://doi.org/10.1016/j. indcrop.2012.09.021

Voziyan, P.A., Hudson, B.G., 2005. Pyridoxamine L the many virtues of a maillard reaction inhibitor. Ann. NY. Acad. Sci. 1043, 807-816. ttps://doi.org/10.1196/ annals.1333.093

Wang, S., Xu, J., Zheng, J., Zhang, X., Shao, J., Zhao, L., Hao, J. 2019. Anti-inflammatory and antioxidant effects of Acetyl-L-Carnitine on antherosclerotic rats. Med. Sci. Monit. 26, 920250-92026. https://doi.org/10.12659/ MSM.920250

Wojdyło, A., Oszmiański, J., Czemerys, R., 2007. Antioxidant activity and phenolic compounds in 32 selected herbs. Food. Chem. 105, 940-949. https://doi.org/10.1016/j. foodchem.2007.04.038

Zhou, J.X, Braun, M., Wetterauer, P., Wetterauer, B., Wink M., 2019. Antioxidant, cytotoxic, and antimicrobial activities of Glycyrrhiza glabra L., Paeonia lactiflora Pall., and Eriobotrya japonica (Thunb.) Lindl. Extracts. Med. 6, 1-16. https://doi.org/10.3390/medicines6020043 